\title{
THE USE OF BAHASA INDONESIA IN LEARNING "ENGLISH SPECIAL PURPOSE" : A STUDY AT MATHEMATIC DEPARTMENT IN IKIP BUDI UTOMO MALANG
}

\author{
Indrawati Pusparini \\ Puspaindra71@gmail.com \\ IKIP Budi Utomo Malang
}

\begin{abstract}
Acquiring English, for several students, can be very tough especially for student that have already used Indonesia language in daily learning. In this extent, The student are seemed in the boundary of learning not acquiring English. In learning English, the student in Ikip Budi Utomo tend to use Bahasa Indonesia, especially who study English Special Purpose in Ikip Budi Utomo. Making use of Bahasa Indonesia might help them a lot in learning English. The researcher, then, was eager to figure out in what way the students who study English Special Purpose in Mathematic department were assisted by Bahasa Indonesia in learning English Special Purpose. The research method used in this study is a qualitative research design.
\end{abstract}

Key words: Learning English, Bahasa Indonesia, English Special Purpose.

CPendidikan Bahasa Inggris FPISH IKIP BU Malang

\section{INTRODUCTION}

English as a global lingua franca is increasingly important and even compulsory in all nations throughout the world in order to be able to communicate effectively. One to each other has prompted the awareness that English must be learned and taught in and outside schools. In Indonesia, for instance, learning and teaching English is conducted extensively in formal schools beginning from early education to university levels. The fact can be seen in that English is one of a few subjects on which emphasis is given.

The strategy is used suppose to that English as a second language in Indonesia that hopefully will lead to official use of it as a medium of communication in education especially and in national as global usage. Unfortunately, the hope still far from the government goal. As we know, there are still difficulty in learning English, either in formal and informal education. Many learners find it burdensome to learn English. In formal schools, many learners think that English is the most difficult subject, even more difficult than other subject, such as mathematics, biology, physics, economics, etc. In the absence of clue to the issue, complaints on how English is learned and taught as well as the large amount of time allotted for English subject emerged and mounted up.

The idea that English is the most difficult language of all languages and very much different from Bahasa Indonesia bringing about conflicting conception on better in learning and teaching English. It may also be blamed for why many English learners find English instruction burdensome. Indeed, the approach of learning and teaching English may be either one of them or both of them.

As we know, the nature of English is specific for Indonesian people because it is not their language. English is as foreign language in Indonesia, though it is taught start from kindergaten up to university, the student still find the burdensome to understand it well. It is true that English is very different from Bahasa Indonesia in terms of phonology,morphology, and syntax. In the level of pronunciation and 
orthography, for instance, English speech sounds do not have conformity with graphic signs, unlike BahasaIndonesia . However English is not more difficult than Bahasa Indonesia and vice versa nor is English the most difficult language of all languages. All human languages, including English can be acquired by all normal individuals.

Why Indonesian learners find it difficult and take a very long time to acquire English is because they don't make using the English language as a daily habit, though they have already learnt from kindergaten. In fact language competence is attained from habit formation. According to (Panggabean, 2007, p. 160), a native speaker acquires his language because he keeps learning by thinking, listening, and speaking in the language he is learning, meaning he learns the language continuously.

Indonesian learners of English indeed spend very little time using and thinking in English. They are really dependent on classroom learning activities that may occur, say twice a week, each of which lasts for one and half hour. In the classroom, their instructors teaching in traditional method may not involve them intensively. This means that the actual time spent in one week is less than two hours, but they speak in Indonesia almoust all the time. Regardless of how many years they have been learning English in this circumstance, the fact is they learn it in weeks instead of years. In language acquisition process, learning in weeks results in very little achievement.

Therefore, this study is aimed to answer the research problem that is in what way Bahasa Indonesia can facilitate Indonesian learner in learning English. This study is considered worthy for me basically as a lecturer and for the English teacher as general to know how they are assisted by Bahasa Indonesia in learning English. Hence, as English teacher we can find one more strategy in explaining the sophisticated thing clearly based on the students' background knowledge. Besides, this study also clarify the way how Bahasa Indonesia use in learning process. Next, the researcher try to investigate how difficult material they have already accepted The previous study also talks about the same issue.therefor, The idea can be formulated as "The use of Bahasa Indonesia in learning English Special Purpose" : a study at mathematic department in Ikip Budi Utomo Malang"

\section{RESEARCH METHOD}

The research method used in this Study is a qualitative research design. Qualitative research method is all about what, how, when, and where the things happen (Berg, 2001). In this study, the data gathered was then analyzed qualitatively to answer the research problem stated previously. The data was gathered from the questionnaire given to the student in mathematic department of Ikip Budi Utomo Malang, the second semester. The participants were 40 students of Ikip Budi Utomo Malang that have already joint in English Spesific Purposes class in 2017. The questionnaire was focused on the students' perception on the use of Bahasa Indonesia in learning English. It includes how Bahasa Indonesia affects them in English learning and how Bahasa Indonesia can assist them to face their problem in learning English either the difficult material for English Special Purpose. After all the data gathered, it was then analyzed qualitatively.

\section{FINDING AND DISCUSSION}

After investigating the student, here the data analyzed that have already listed in the table below : 
Table 1.The use bahasa Indonesia in learning process

\begin{tabular}{|l|c|}
\hline \multicolumn{1}{|l|}{ Students' opinion } & Total number \\
\hline \hline agree & $85 \%$ \\
\hline disagree & $10 \%$ \\
\hline Not answer & $5 \%$ \\
\hline T O T A L & $100 \%$ \\
\hline
\end{tabular}

Table 2. The way in use bahasa Indonesia

\begin{tabular}{|l||l|}
\hline Students' opinion & Total number \\
\hline $\begin{array}{l}\text { Only use Bahasa } \\
\text { Indonesia }\end{array}$ & $15 \%$ \\
\hline Only use English & $10 \%$ \\
\hline $\begin{array}{l}\text { Use English and } \\
\text { Bahasa Indonesia }\end{array}$ & $65 \%$ \\
\hline Not answer & $10 \%$ \\
\hline T O T A L & $100 \%$ \\
\hline
\end{tabular}

Table 3. The difficult material according to student

\begin{tabular}{|l||c||}
\hline \multicolumn{1}{|l||}{ Students' opinion } & Total number \\
\hline \hline Structure & $25 \%$ \\
\hline Listening & $30 \%$ \\
\hline Speaking & $25 \%$ \\
\hline Reading & $15 \%$ \\
\hline Not answer & $5 \%$ \\
\hline T O T A L & $100 \%$ \\
\hline
\end{tabular}

Based on the data got from questionnaire given to 40 students in the second semester of mathematic,Ikip Budi Utomo Malang,the researcher got that $85 \%$ of the students agree that the understanding of Bahasa Indonesia help them to learn English. While there is only $10 \%$ who did not really agree with such statement, and $5 \%$ not answer the questionare.

While the data that got from second question were : $15 \%$ student agree only use English in learning process, $10 \%$ agree only use Indonesia language, $65 \%$ agree use Bahasa
Indonesia and English, and the rest $10 \%$ not answer the questionare.

Based on those data, the researcher to prove their statement in order to find in what way Bahasa Indonesia can help them in learning English. In this case, the researcher tried to have a field study concerning the above issue. Based on the experience in the teaching and learning process, the students tend to use Bahasa Indonesia in explaining the idea to their friend in the small group discussion. Sometimes, they also asked the teacher to explain in Bahasa Indonesia when they got difficulty in understanding the materials. In English Special Purpose class, they often asked the teacher like what we call that meaning in Bahasa Indonesia. From this phenomenon, the researcher are eager to find out in what way they are assisted by Bahasa Indonesia when they are learning English. Then, the researcher tried to investigate in what way Bahasa Indonesia can help them in learning English by asking them which materials they feel easier than others.

Based on the data gathered from 40 students of Mathematic Department that joining English Special Purpose class in Ikip Budi Utomo Malang, the researcher got that $25 \%$ of the students considered that structure were the most difficult material. While $30 \%$ of them considered that listening were the most difficult material. Twenty five percent of the students considered that speaking is the most difficult one; the rest about $15 \%$ considered that reading it difficult. Then, there are still \% \% that student do not answer the questionare

Based on the above-data, it can be concluded that most of the students considered that listening was the most difficult material. This material does not exists in Bahasa Indonesia, so they have no background knowledge concerning this material. Sometimes, they said because the speed of native speaker is 
too fast. In this case, the lecturer sometimes feel difficult in explaining the material which has no equivalent with their background knowledge. While for stucture, the second one in difficulties, the students felt those difficult because they need to memorize which verbs and also the confusing of adverb of time. When they were informed that tense needs adverb of time for present, past and future, they directly understood though Bahasa Indonesia does not have such structure. Twenty five percent of them considered that speaking was the most difficult for the only way to know the speaking of English is only by memorizing; that makes this material difficult. In fact, speaking is not memorizing, but it skill reproducing that include for structure and sometimes also the gain of vocabulary. The rest of the students considered that reading is the most difficult; again this is because it needs memorizing a lot of vocabulary in English. Some of them because of reading habit, they student tend to being lazy when they find difficulties in memorizing a new vocabualry or get a long passage in reading.

\section{CONCLUTION AND SUGGESTION}

Based on the previous explanation above, it can be drawn some conclusion that the use of Bahasa Indonesia is very prominent for Indonesian learners in learning English especially for English for Special Purposes. Bahasa Indonesia gives them background knowledge in learning language since there are some similarities between Bahasa Indonesia and English. The more the similarities between Bahasa Indonesia and the target language the easier the learners learn the target language. For the future researchers, they may do the similar study in a broader context and see the effectiveness of using Bahasa Indonesia in learning English for learners. Besides they may do a study with the same topic in different context.

Besides, Misleading conception on the nature of English and how they are learned and taught result in complaints have lead to amendment of 2013 English curriculum in Indonesia. Because of the misleading conception that English is the most difficult language along with other subject, English should be approached with grammar or learning it with specific strategies or the same process as learning first language. English is not more difficult than Indonesian language, Bahasa Indonesia and the other languages. Why Indonesian speaking learners of English find it difficult and take a very long time to acquire English is due to limited time spent to learn it, they only use English around half and a hour for only once or twice a week depending on the school's schedule. The ather, they using English is not a habit, they do not tend to use English in daily learning language. When knowing the nature of English, the learners will not find the instruction burdensome and difficult.

In the countries where English is used as a second language such as Malaysia and Singapore, people can communicate in English though they learn the language without learning grammar. Unlike Indonesian people learning English in formal instruction using grammar approach, they learn the language just the way they learn their mother tongues. In order for Indonesian people to be able to communicate in English like Malaysians and Singaporeans, they should learn English just the way Malaysians and Singaporeans do. Unfortunately, Indonesian learning atmosphere is different from those of in Malaysia and Singapore. Why Malaysians and Singaporeans can learn English naturally is because of the situation that prompts 
them to use English, such as government policy establishing English as a second language.

With this in mind, it is important that English be formally declared as a second language in Indonesia. English were a second language in Indonesia. We can use the language creatively for daily purposes.This kind of learning process is the condition that needs to be created. It is understandable that it takes time to create atmosphere in Indonesia but there must be awareness that Indonesian people should start learning English outside classroom. They don't need to be reluctant of using English because of fear of making mistakes in grammar, pronunciation, and intonation.

\section{REFERENCES}

Arikunto, Suharsimi. 2002. Metodologi Penelitian. Penerbit PT. Rineka Cipta. Jakarta

Berg, B. L. (2001). Qualitative Research Method for the Social Science: Fourth Edition USA

: A Pearson Education Company

Borg, R.W., \& Gall. M.D. 1983.

Educational Research: An Introduction $\left(4^{\text {th }}\right.$ ed.). New York and London: Longman Inc.

Nana Saodih Sukmadinata. 2006. Metode penelitian pendidikan, Bandung: Remaja Rosdakarya.

Mistar, Junaidi, 2005.Bahan Ajar Research Methodology. Malang, UNISMA.

Punchihetti, S. (2013). First, Second, and Foreign Language Learning:How Distinctive are They from One Another? The

EuropeanConference on

Language Learning 2013.
Srilanka: The

InternationalAcademic Forum .

Sugiyono. 2007. Metode penelitian pendidikan kuantitatif, kualitatif, dan $R \& D$. Bandung: ALFABETA

Murray, D. E. (2005). First Language

Support in Adul ESL in Australia.

Sydney: National

Centre for English Language

Teaching and Research . 